

\section{DISCLAIMER}

This report was prepared as an account of work sponsored by an agency of the United States Government. Neither the United States Government nor any agency Thereof, nor any of their employees, makes any warranty, express or implied, or assumes any legal liability or responsibility for the accuracy, completeness, or usefulness of any information, apparatus, product, or process disclosed, or represents that its use would not infringe privately owned rights. Reference herein to any specific commercial product, process, or service by trade name, trademark, manufacturer, or otherwise does not necessarily constitute or imply its endorsement, recommendation, or favoring by the United States Government or any agency thereof. The views and opinions of authors expressed herein do not necessarily state or reflect those of the United States Government or any agency thereof. 


\section{DISCLAIMER}

Portions of this document may be illegible in electronic image products. Images are produced from the best available original document. 


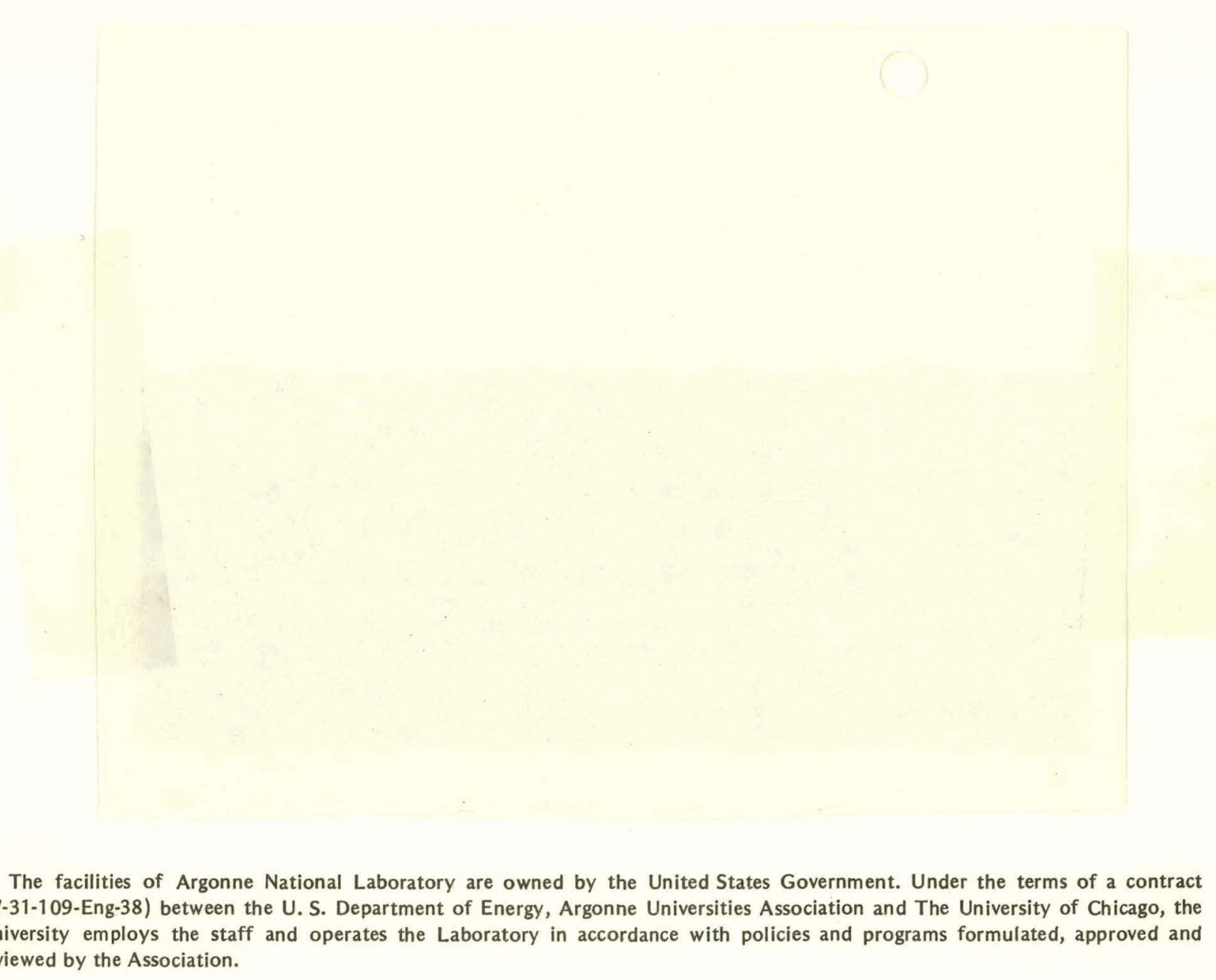
reviewed by the Association.

\section{MEMBERS OF ARGONNE UNIVERSITIES ASSOCIATION}

The University of Arizona Carnegie-Mellon University Case Western Reserve University

The University of Chicago

University of Cincinnati

Illinois Institute of Technology

University of Illinois

Indiana University

Iowa State University

The University of lowa

\author{
Kansas State University \\ The University of Kansas \\ Loyola University \\ Marquette University \\ Michigan State University \\ The University of Michigan \\ University of Minnesota \\ University of Missouri \\ Northwestern University \\ University of Notre Dame
}

The Ohio State University Ohio University

The Pennsylvania State University

Purdue University

Saint Louis University

Southern Illinois University

The University of Texas at Austin

Washington University

Wayne State University

The University of Wisconsin

\section{NOTICE}

This report was prepared as an account of work sponsored by the United States Government. Neither the United States nor the United States Department of Energy, nor any of their employees, flur diry of their contractors, subcontractors, or their employees, makes any warranty, express or implied, or assumes any legal liability or responsibility for the accuracy, completeness or usefulness of any information, apparatus, product or process disclosed, or represents that its use would not infringe privately-owned rights. Mention of commercial products, their manufacturers, or their suppliers in this publication does not imply or connote approval or disapproval of the product by Argonne National Laboratory or the U. S. Department of Energy. 
ANL/CNSV-TM-19, Vol. 1

\author{
ARGONNE NATIONAL LABORATORY \\ 9700 South Cass Avenue \\ Argonne, Illinois 60439
}

\title{
PHILADELPHIA'S GALLERY II SHOPPING CENTER COMPLEX: \\ AN ANALYSIS FOR THE APPLICATION OF AN \\ INTEGRATED COMMUNITY ENERGY SYSTEM
}

Vol. 1: Executive Summary

by

C. Lee, A. Davis, and R. Kron

Energy and Envi ronmental Systems Division

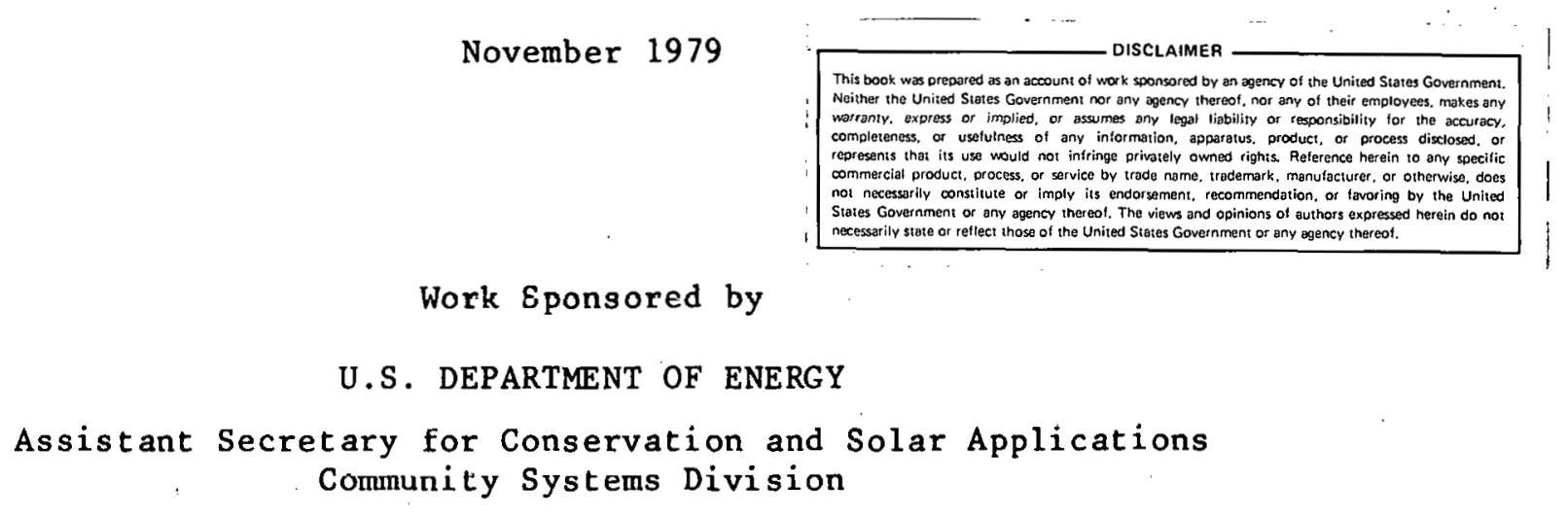


This informal report presents preliminary results of ongoing work or work that is more limited in scope than that described in formal reports issued by the Energy and Envi ronmental Systems Division.

This report is available from

National Technical Information Service

U.S. Department of Commerce 5285 Port Royal Road

Springfie1d, Virginia 22161 
ABSTRACT. . . . . . . . . . . . . . . . . . . . . . . . . 1

1 INTRODUCTION . . . . . . . . . . . . . . . . . . . . . . 1

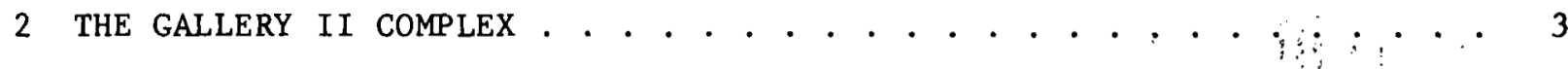

2.1 LOCATION AND ARCHITECTURE . . . . . . . . . . . . . . . . . 3

2.2 ENERGY LOAD CHARACTERISTICS . . . . . . . . . . . . . . . . . 3

3 CANDIDATE ENERGY SYSTEMS FOR GALLERY II. . . . . . . . . . . . . . . . 7

4 COMPARISON OF ENERGY SYSTEM ALTERNATIVES FOR GALLERY II. $: . . . . \ddots^{\prime} \cdot 9$

4.1 General EVALUATiON CRITERIA . . . . . . . . . . . . . . . . . . 9

4.2 RELIABILITY, FUEL AVAILABILITY, ENVIRONMENTAL EFFECTS AND EXPANDABILITY . . . . . . . . . . . . . . . . . . . . 9 9

4.3 ENERGY AND SCARCE-FUEL ANALYSIS . . . . . . . . . . . . . . . . . 9

4.4 ECONOMICS . . . . . . . . . . . . . . . . . . . . . . . . . 11

4.5 CONCLUSION. . . . . . . . . . . . . . . . . . . 15

5 DESCRIPTION OF THE RECOMMENDED SYSTEM HEAT-PUMP-CENTERED ICES . . . . 17

5.1 INTRODUCTION. . . . . . . . . . . . . . . . . . . . 17

5.2 HEAT-PUMP SYSTEM OPERATION. . . . . . . . . . . . . . . . . 17

6 RECOMMENDATION . . . . . . . . . . . . . . . . . . . . . 21

APPENDIX . . . . . . . . . . . . . . . . . . . . . . 23

ACKNOWLEDGMENTS . . . . . . . . . . . . . . . . . . . 25 
Figure

2.1 Location of Gallery II . . . . . . . . . . . . . . . . . . . . 4

2.2 Site Plan of Gallery II. . . . . . . . . . . . . . . . . . . 5

2.3 Longitudinal Section of Gallery II . . . . . . . . . . . . . . . . . 6

5.1 Schematic of Heat-Pump-Centered ICES . . . . . . . . . . . . . . 18

\section{LIST OF TABLES}

Table

2.1 Gallery II - Buildings and Areas . . . . . . . . . . . . . . 3

2.2 Peak Loads of Gallery II Complex . . . . . . . . . . . . . . . . 3

4.1 Energy Savings of Candidate ICES . . . . . . . . . . . . . . . . . 10

4.2 Scarce Fuel Savings of Candidate ICES. . . . . . . . . . . . . . . 12

4.3 System Costs of Candidate ICES . . . . . . . . . . . . . . . . . . . 13

4.4 Economics of ICES Compared to the Conventional System. . . . . . . . 14 


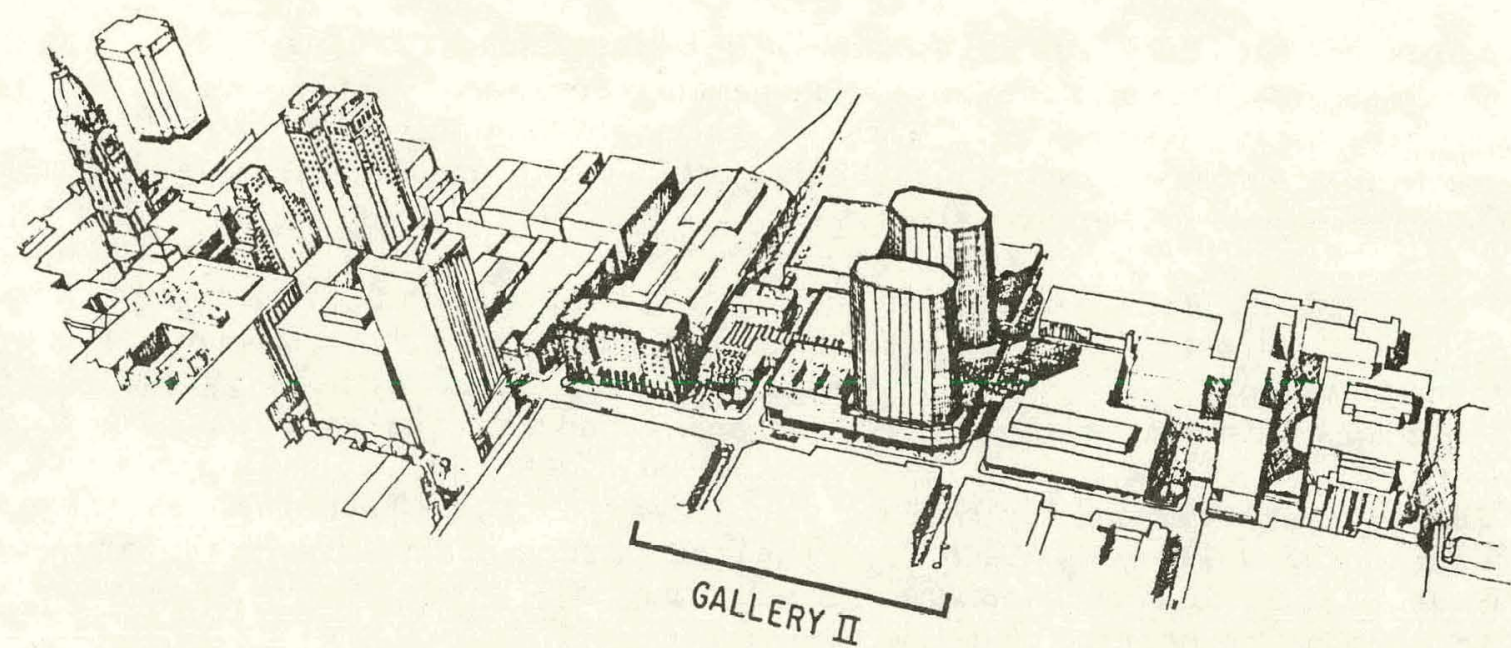

Artist's Conception of Market Street East Redevelopment Area

\author{
PHILADELPHIA'S GALLERY II SHOPPING CENTER COMPLEX : \\ AN ANALYSIS FOR THE APPLICATION OF AN \\ INTEGRATED COMMUNITY ENERGY SYSTEM
}

\title{
ABSTRACT
}

This report summarizes the results of ANL's study of the energy and economic aspects of energy system options for the Gallery II development. Gallery II is a $1.3 \mathrm{milli}$ on $\mathrm{ft}^{2}$ office and shopping complex to be built in downtown Philadelphia. Seven centralized energy system alternatives, including five total energy systems and two heat-pump systems, were analyzed and compared with a decentralized, al1-electric, conventional system. Comparisons among systems indicate that, in today's economy, the heat-pump-centered system which redistributes heat among different zones of buildings through the operation of heat pumps can achieve significant energy and economic savings.

\section{INTRODUCTION}

Gallery II is a 1.3 million $\mathrm{ft}^{2}$ shopping and office development proposed for the Market Street East Redevelopment Area in downtown Philadelphia. This massive complex, an extension of the highly successful Gallery I shopping center, is part of a joint venture by private developers and the city to help improve the downtown business climate through improved urban services.

The main organizations developing Gallery II are The Rouse Company, J.C. Penney Realty, Cadillac-Fairview, and the City of Philadelphia. Partly 
because of the City of Philadelphia's Department of Energy (DOE) sponsored Comprehensive Community Energy Management Program (CCEMP) and a desire to lower energy costs to stimulate private investment, the City CCEMP staff became interested in the possibility of developing an Integrated Community Energy System (ICES)* for Gallery II.

DOE's CCEMP program is being funded and managed through Argonne National Laboratory (ANL), a federally funded research institution operated by the University of Chicago. The Energy and Environmental Systems Division of ANL has responsibility for CCEMP and conducts studies of many topics, an important one of which is the evaluation, development, and application of ICES. In mid 1979, City CCEMP staff asked ANL for technical assistance in studying the Gallery II ICES opportunity. After discussion with City and the Market Street East Development Corporation, ANL entered the Gallery II study with several objectives and limits in mind:

1. ANL was to study the technical and economic feasibility of various ICES for Gallery II. Social, political, legal, and environmental impacts should be given consideration by local organizations more familiar with the local situation.

2. DOE and ANL are interested in discovering what local government $c$ an do to promote ICES implementation. The results of Philadelphia's experience could be extended to other CCEMP communities, agencies participating in the Farmer's Home Administration (FmHA) and DOE sponsored Smal1 Town Energy Planning (STEP) program, or to others interested in local energy management.

3. The Gallery II project is designed to test a model for DOE technical assistance. The objective is to see if ANL, by providing some preliminary design work, can break through the inertia that may keep a good ICES project from coming on line.

4. ANL's study was to lead to the conceptual design of an ICES for Gallery II. Extensive work by engineering consultants will be required to complete preliminary and final designs of the system.

\footnotetext{
*An introduction to ICES is presented in the Appendix.
} 


\subsection{LOCATION AND ARCHITECTURE}

When Gallery II is completed in 1987 , it will be an ultra-modern structure encompassing two 25-story office towers, a 4-level shopping mal1, and a 4-level J.C. Penney store. The entire complex will contain 1.3 million $\mathrm{ft}^{2}$ of floor space, divided as shown in Table 2.1.

Gallery II will be built in the Market Street East Redevelopment area of Philadelphia. A map showing Gallery II's location is given in Fig. 2.1. Figures 2.2 and 2.3 provide a site plan and a longitudinal section, respectively.

\subsection{ENERGY LOAD CHARACTERISTICS}

The community energy loads for lighting, power, space heating, space cooling and domestic hot water were estimated on the bases of local climatological data and on data supplied by the Market Street East Corporation. Daily load profiles for peak winter and summer days and typical days of each season were established according to occupancy patterns of the buildings and the climatological data. Table 2.2 summarizes peak loads.

Table 2.1. Gallery II Buildings and Areas

\begin{tabular}{lr}
\hline \multicolumn{1}{c}{ Buildings } & \multicolumn{1}{c}{$\begin{array}{c}\text { Areas } \\
\left(\mathrm{ft}^{2}\right)\end{array}$} \\
\hline North and South Office Towers & 880,000 \\
J.C. Penney & 250,000 \\
Gallery II Shopping Mall & $\underline{170,000}$ \\
Total & $1,300,000$ \\
\hline
\end{tabular}

Table 2.2. Peak Loads of Gallery II Complex (MW)

\begin{tabular}{lccrr}
\hline \multicolumn{1}{c}{ Service } & $\begin{array}{r}\text { Gallery II } \\
\text { Mal1 }\end{array}$ & J.C. Penney & $\begin{array}{r}\text { Office } \\
\text { Towers }\end{array}$ & Total \\
\hline Lighting & 0.51 & 0.75 & 2.61 & 3.90 \\
Power & 0.51 & 0.75 & 3.52 & 4.78 \\
Heating & 1.49 & 2.20 & 9.02 & 12.71 \\
Cooling & 2.04 & 3.00 & 12.10 & 17.14 \\
Domestic Hot & 0.04 & 0.05 & 0.23 & 0.32 \\
$\quad$ Water Heating & & & & \\
\hline
\end{tabular}




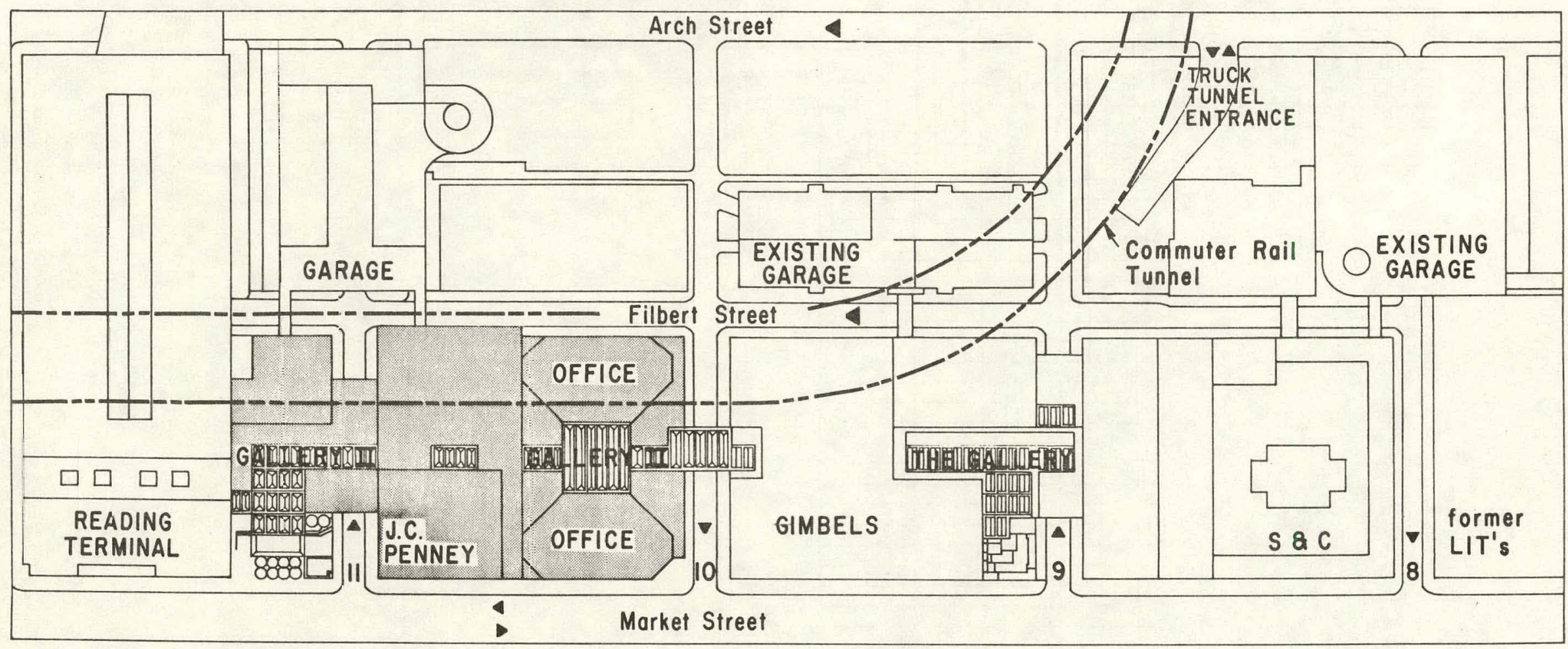




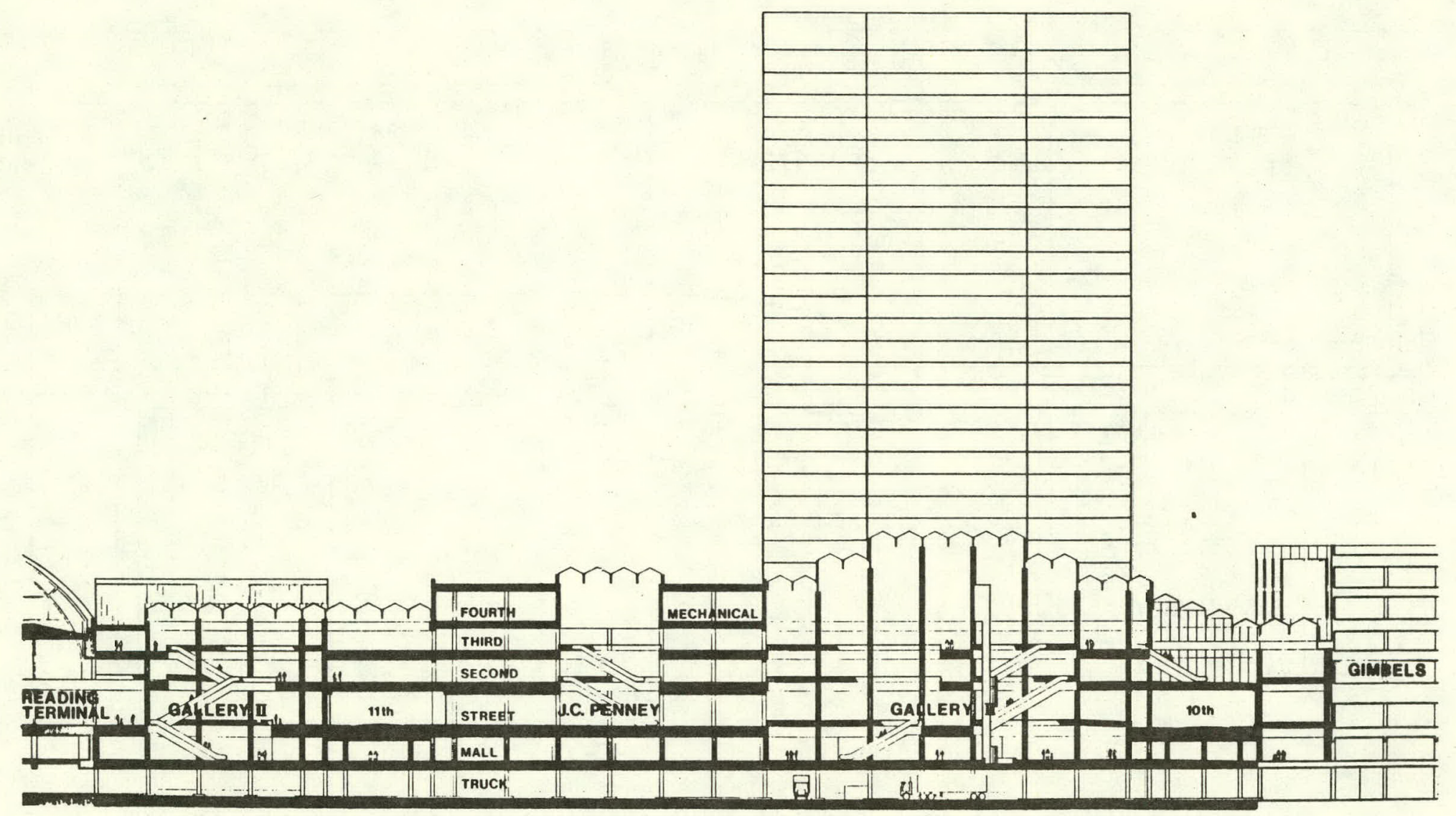

Fig. 2.3. Longitudinal Section of Gallery II 


\section{CANDIDATE ENERGY SYSTEMS FOR GALLERY II}

Several energy technologies suggested for Gallery II have been ruled out for various reasons. For example, solar heating was eliminated because of inadequate roof area for solar collectors. Even if the entire roofs of the two office towers, J.C. Penney and the Gallery II mall were covered with solar panels, they would absorb less than $6 \mathrm{MW}$ of heat (maximum); whereas a peak of $13 \mathrm{MW}$ is required.

Coal-fired systems, although good candidates. for scarce-fuel substitution, were rejected because of the air pollution they would create in downtown Philadelphia. The downtown area already is a National Ambient Air Quality Standard (NAAQS) non-attainment area; any addition to the particulate or sulfur dioxide $\left(\mathrm{SO}_{2}\right)$ concentrations would worsen the problem. Waste disposal systems, such as large-scale incinerators with heat recovery, were ruled out because of the air quality problems cited above and the aesthetic and traffic problems that may result. Energy systems with steam turbines as prime movers were not considered good options for the following reasons: (1) two huge high-pressure industrial steam generators, each over 5,000 boiler horse-power (bhp), would be required and erected outside the buildings, and (2) a stack higher than the surrounding buildings would be required. Both problems would present space and aesthetic problems in the center city.

In considering the characteristics of the Gallery II complex and its environmental limitations, the following four energy technologies appear to be appropriate:

(1) all-electric conventional system;

(2) internal combustion engine total energy systems:

(a) diesel engine

(b) gas engine (otto cycle)

(c) dual-fuel engine

(3) gas turbine (Brayton cycle) total energy systems:

(a) oil fired

(b) gas fired

(4) heat-pump-centered system:

(a) using Delaware River water as heat sink/source

(b) without exterior heat source

The all-electric conventional system, which uses electricity purchased from Philadelphia Electric Company (PECO), is a decentralized system in which each building has its own heating and cooling generating devices. It utilizes compression chillers as cooling devices and electric resistance heaters as heating devices.

The total energy systems include a central plant that uses oil or gas to produce both electricity and thermal energy (cogeneration), and a distribution network that conveys the energy generated to buildings where energy is consumed. In a cogeneration plant, the prime mover and generator sets produce electricity. Heat, released to the exhaust gas, jacket water, and/or 
lube oil, is recovered and used for space-heating, domestic hot water, or to run absorption chillers for cooling purposes. The total energy system supplies the entire energy needs of the community without connection to an electric utility such as PECO.

The heat-pump-centered systems employ electrically driven, two-stage, double-bundle, water-to-water heat pumps in a central heating and cooling plant to provide the space-conditioning needs of the complex. There would be no on-site generation of electricity. Electricity required for the operation of the plant and for lighting, power, and domestic hot water heating in the buildings would be purchased from PECO as in the conventional system. A heat pump transfers heat from where it is available (or undesirable) to where it is required (or acceptable). It has the ability of simultaneously providing heating and cooling and thus, is an excellent method for energy conservation.

One of the heat pump systems studied would make use of water from the nearby Delaware River as a heat source/sink for the heat pumps. The existence of a subway tunnel between the river and the Market Street site would reduce the water transportation cost and increase the feasibility of the system. The other heat pump system studied would use no external heat source. Instead, through the operation of heat pumps, it would redistribute heat generated at the interior zones of buildings (where it is undesirable) to the exterior zones (where it is required) in the heating seasons. The cooling loop of the system transports the heat to heat pumps which, in turn, pump it to the heating loops. In both heat-pump systems, auxiliary boilers supplement any deficiency in space-heating demand.

The central plant of all the ICES studied is assumed to be located in the basement of the North Tower. 
4 COMPARISON OF ENERGY SYSTEM ALTERNATIVES FOR GALLERY II

\subsection{GENERAL EVALUATION CRITERIA}

In general, the following seven factors will play important roles in determining whether an ICES concept is feasible and, if so, the type of system to be implemented:

(1) economics

(2) reliability

(3) availability of fuel

(4) envi ronmental effects
(5) expandability

(6) energy savings

(7) substitution or conservation of scarce fuels

The economics would determine.if the investment or additional investment in an ICES can be justified. The reliability of an ICES is the degree of ability of providing services when they are required. Fuel availability refers to fuel supply for the operation of the energy systems. Environmental effects relate primarily to air and water quality impact on the site. Expandability measures the ability of the energy system to be enlarged to satisfy additional energy loads.

\subsection{RELIABILITY, FUEL AVAILABILITY, ENVIRONMENTAL EFFECTS AND EXPANDABILITY}

Each of the total energy systems is designed to have at least two prime movers. With an extra unit as standby, the system would be a highly reliable energy supplier. However, availability of oil and natural gas to drive the total energy systems might pose a problem. Recent uncertainty in supply and considerable price increases have caused anxiety over recommending energy systems that utilize such fuels.

The heat-pump-centered system, which uses electric energy from PECO, is at least as reliable as the conventional system. Better backup characteristics can be provided because the central plant has more cooling devices than would be available in any individual building.

Air pollution, particularly nitrogen oxides, produced by the total energy systems could cause air quality problems. The heat-pump systems.would cause no air pollution, and the effects of thermal pollution on the Delaware River would be minimal. No problems are expected as to the expandability of ICES, as long as any expected new loads are taken into account in the initial design of subsystems, e.g., in the distribution network.

\subsection{ENERGY AND SCARCE-FUEL ANALYSIS}

The energy requirements of candidate ICES were compared to those of the conventional system, and the savings are presented in Table 4.1. The conventional system would consume $6.37 \times 10^{7} \mathrm{kWh} / \mathrm{yr}$ of electricity and 
Table 4.1. Energy Savings of Candidate ICES

\begin{tabular}{|c|c|c|c|c|c|}
\hline System Type & $\begin{array}{l}\text { Energy } \\
\text { Type }\end{array}$ & $\begin{array}{r}\text { Energy Input } \\
\quad(\text { Per Year) }\end{array}$ & $\begin{array}{l}\text { Preliminary } \\
\text { Fuel Input } \\
\text { (But/Y) }\end{array}$ & $\begin{array}{l}\text { Fue 1 Saved } \\
(B t u / Y)\end{array}$ & $\begin{array}{l}\% \text { of Fue } 1 \\
\text { Saved vs. } \\
\text { Conven- } \\
\text { tional }\end{array}$ \\
\hline \multicolumn{6}{|l|}{ Internal Combustion Engines } \\
\hline $\begin{array}{l}\text { Diesel Engines } \\
\text { Gas Engines } \\
\text { Dual Fuel }\end{array}$ & $\begin{array}{l}\# \text { 非 Oil } \\
\text { Natural Gas } \\
\sharp 16 \text { Oil and } \\
\text { Natural Gas }\end{array}$ & $\begin{array}{l}4.56 \times 10^{11} \text { Btu } \\
6.35 \times 10^{11} \text { Btu } \\
5.61 \times 10^{11} \text { Btu }\end{array}$ & $\begin{array}{l}4.56 \times 10^{11} \\
6.38 \times 10^{11} \\
5.61 \times 10^{11}\end{array}$ & $\begin{array}{l}2.69 \times 10^{11} \\
0.87 \times 10^{11} \\
1.64 \times 10^{11}\end{array}$ & $\begin{array}{l}37 \\
12 \\
23\end{array}$ \\
\hline \multicolumn{6}{|l|}{ Gas Turbines } \\
\hline $\begin{array}{l}\text { Gas Fired } \\
\text { Oil Fired }\end{array}$ & $\begin{array}{l}\text { Natural Gas } \\
\text { 非 Oil }\end{array}$ & $\begin{array}{l}5.57 \times 10^{11} \text { Btu } \\
5.57 \times 10^{11} \text { Btu }\end{array}$ & $\begin{array}{l}5.57 \times 10^{11} \\
5.57 \times 10^{11}\end{array}$ & $\begin{array}{l}1.68 \times 10^{11} \\
1.68 \times 10^{11}\end{array}$ & $\begin{array}{l}23 \\
23\end{array}$ \\
\hline $\begin{array}{l}\text { Heat-Pump Centered System } \\
\text { Heat-Pump-Centered System } \\
\text { with River Water }\end{array}$ & Grid Electricity & $5.19 \times 10^{7} \mathrm{kWh}$ & $5.90 \times 10^{11}$ & $1.35 \times 10^{11}$ & 19 \\
\hline
\end{tabular}


require $7.25 \times 10^{11} \mathrm{Btu} / \mathrm{yr}$ of preliminary fuel input at the PECO generating stations.*

Scarce fuel savings are listed in Table 4.2. The scarce fuel used at the PECO generating stations is $31.8 \% * *$ of the total fuel consumed. Therefore, scarce-fuel consumption by the conventional system is $2.32 \times 10^{11}$ Btu/yr. As shown in Tables 4.1 and 4.2 , the total energy systems -- especially the diesel engine system -- are efficient energy savers. Nevertheless, because they consume more scarce fuel than the conventional system, they are not good candidates from the viewpoint of scarce-fuel conservation. Heat-pump systems are good energy and scarce fuel savers.

\subsection{ECONOMICS}

Table 4.3 sumarizes the expected capital expenditures and operation/ maintenance costs of the candidate systems. Capital costs include the central plant (up to the building boundary) and the in-building systems for the Gallery II mall and the two office towers. It is expected that J.C. Penney's in-building system will be installed and maintained by its own personnel. The owner of the ICES -- most likely the Market Street East Development Corporation -- should try to convince J.C. Penney to connect to the ICES. This should not be difficult because, by connecting to an ICES, J.C. Penney will be able to secure advantages in equipment and fuel economy if an ICES is proved to be feasible. For purposes of this study, J.C. Penney's continued independence is assumed, and the store's in-building system and operation/ maintenance costs are not included in the following economic analysis.

The cost of the central plant for each ICES is obtained by cost itemizing system components in the plant. In-building system costs include plumbing, heating, ventilation and air conditioning (HVAC), and electrical systems. The conventional system cost is based on cost records of Gallery I with the system costs for offices adjusted according to Mean's Mechanical \& Electrical Cost Data (1979) which provides average square-foot building costs with respect to building types. The in-building system costs for ICES take into account the differences in components between ICES and the conventional system. These differences include: (1) the addition of heat exchangers for domestic hot water, $* * *$ in-building hot water distribution, and two water pipes, if necessary, for central plant cooling towers; and (2) the omission of chillers, cooling towers in individual buildings, electric resistance heaters in fan coil units and electric domestic hot water heaters. The size of the mechanical room in each building also would be reduced by about $50 \%$.

\footnotetext{
*The average efficiency of the PECO generating plants and transmission and distribution systems is assumed to be $30 \%$.

**The fuel mix of PECO in 1978 was: $37.8 \%$ coal, $31.8 \%$ oil, $26.3 \%$ nuclear, and $4.1 \%$ hydropower.

***Domestic hot water heaters still would be required in the heat-pump system; therefore, no domestic hot water heat exchangers would be needed.
} 
Table 4.2. Scarce Fuel Savings of Candidate ICES

\begin{tabular}{|c|c|c|c|}
\hline System Type & $\begin{array}{l}\text { Scarce Fuel Used } \\
(B \leftarrow u / Y)\end{array}$ & $\begin{array}{l}\text { Scarce Fuel Saved } \\
(B t u / Y)\end{array}$ & $\begin{array}{l}\% \text { of Scarce } \\
\text { Fuel Saved } \\
\text { vs. Conven- } \\
\text { tional }\end{array}$ \\
\hline \multicolumn{4}{|l|}{ Internal Combustion Engines } \\
\hline $\begin{array}{l}\text { Diesel Engines } \\
\text { Gas Engines } \\
\text { Dual-Fuel }\end{array}$ & $\begin{array}{l}4.56 \times 10^{11} \\
6.38 \times 10^{11} \\
5.61 \times 10^{11}\end{array}$ & $\begin{array}{l}-2.24 \times 10^{11} \\
-4.06 \times 10^{11} \\
-3.29 \times 10^{11}\end{array}$ & $\begin{array}{l}(97)^{a} \\
(175) \\
(142)\end{array}$ \\
\hline \multicolumn{4}{|l|}{ Gas Turbines } \\
\hline $\begin{array}{l}\text { Gas Fired } \\
\text { Oil Fired }\end{array}$ & $\begin{array}{l}5.57 \times 10^{11} \\
5.57 \times 10^{11}\end{array}$ & $\begin{array}{l}-3.25 \times 10^{11} \\
-3.25 \times 10^{11}\end{array}$ & $\begin{array}{l}(140) \\
(140)\end{array}$ \\
\hline Heat-Pump Centered System & $1.89 \times 10^{11}$ & $0.43 \times 10^{11}$ & 19 \\
\hline $\begin{array}{l}\text { Heat Pump Centered System } \\
\text { with River Water }\end{array}$ & & & \\
\hline $\begin{array}{l}\text { W/O River Water Return } \\
\text { With River Water }\end{array}$ & $\begin{array}{l}1.77 \times 10^{11} \\
1.81 \times 10^{11}\end{array}$ & $\begin{array}{l}0.55 \times 10^{11} \\
0.51 \times 10^{11}\end{array}$ & $\begin{array}{l}24 \\
22\end{array}$ \\
\hline
\end{tabular}

$a_{P}$ arentheses denote that the ICES would use more scarce fuel than the conventional system.

Operation and maintenance costs include personnel and material required, insurance, and property tax on the property. The conventional system is assumed to be under a service contract to provide material and staff for operation and maintenance. With ICES, the operation and maintenance of the in-building systems, other than J.C. Penney's system, is assumed to be performed by personnel employed by the ICES owner and dispatched from the central plant. This results in lower personnel expenses for ICES; however, two extra engine engineers would have to be employed for total energy systems.

For energy costs, the rate for electricity purchased from PECO is averaged at $3 \notin / \mathrm{kWh}$, and natural gas purchased from Philadelphia Gas Works (PGW) at $\$ 2.56 / 10^{6} \mathrm{Btu}$ (or $\$ 2.60 / 1000 \mathrm{ft}^{3}$, which is $90 \%$ of the general rate). The price of $\|^{\prime} 6$ oil is estimated at $\$ 3.00 / 10^{6}$ Btu or $45 \notin / g a l$.

Switching from the conventional operating system to ICES increases the initial capital investment but saves in annual costs. For an ICES, personnel expenses are lower, but the insurance and property $t a x$ are higher. This leads to the situation that some ICES have higher $0 / M$ costs than those of the conventional system. Nevertheless, to satisfy the energy requirements of the complex, it costs less overall (in $O / M$ and fuel costs) to operate an ICES than a conventional system.

The first column of Table 4.4 lists incremental capital expenditures for ICES over the conventional system. The extra capital requirement should 
Table 4.3. System Costs of Candidate ICES (1979\$)

\begin{tabular}{|c|c|c|c|c|c|c|c|}
\hline \multirow[b]{2}{*}{ System Type } & \multicolumn{3}{|c|}{ Capital } & \multicolumn{3}{|c|}{$0 / M$} & \multirow[b]{2}{*}{ Energy } \\
\hline & Plant & In-Building & Total & Plant & In-Building & Total & \\
\hline Conventional & 0 & $16.87 \times 10^{6}$ & $16.87 \times 10^{6}$ & 0 & $9.81 \times 10^{5}$ & $9.81 \times 10^{5}$ & $1.91 \times 10^{6}$ \\
\hline \multicolumn{8}{|l|}{ Internal Combuation Engines } \\
\hline $\begin{array}{l}\text { Diesel } \\
\text { Gas } \\
\text { Dual-Fuel } \\
\text { Gas } \\
\text { Oil }\end{array}$ & $\begin{array}{r}11.03 \times 10^{6} \\
7.98 \times 10^{6} \\
10.06 \times 10^{6} \\
9.51 \times 10^{6} \\
10.22 \times 10^{6}\end{array}$ & $\begin{array}{l}15.08 \times 10^{6} \\
15.08 \times 10^{6} \\
15.08 \times 10^{6} \\
15.02 \times 10^{6} \\
15.02 \times 10^{6}\end{array}$ & $\begin{array}{l}26.11 \times 10^{6} \\
23.06 \times 10^{6} \\
25.68 \times 10^{6} \\
24.53 \times 10^{6} \\
25.24 \times 10^{6}\end{array}$ & $\begin{array}{l}7.82 \times 10^{5} \\
6.81 \times 10^{5} \\
7.64 \times 10^{5} \\
7.16 \times 10^{5} \\
7.52 \times 10^{5}\end{array}$ & $\begin{array}{l}4.52 \times 10^{5} \\
4.52 \times 10^{5} \\
4.52 \times 10^{5} \\
4.51 \times 10^{5} \\
4.51 \times 10^{5}\end{array}$ & $\begin{array}{l}12.34 \times 10^{5} \\
11.33 \times 10^{5} \\
12.16 \times 10^{5} \\
11.67 \times 10^{5} \\
12.03 \times 10^{5}\end{array}$ & $\begin{array}{l}1.37 \times 10^{6} \\
1.64 \times 10^{6} \\
1.53 \times 10^{6} \\
1.43 \times 10^{6} \\
1.67 \times 10^{6}\end{array}$ \\
\hline $\begin{array}{l}\text { Heat-Pump Centered System } \\
\text { Heat Pump Ceatered System } \\
\text { with Biver Water }\end{array}$ & $2.84 \times 10^{6}$ & $15.01 \times 10^{6}$ & $17.85 \times 10^{6}$ & $4.23 \times 10^{5}$ & $4.50 \times 10^{5}$ & $8.73 \times 10^{5}$ & $1.56 \times 10^{6}$ \\
\hline $\begin{array}{l}\text { W/O River Water Return } \\
\text { With River Water Return }\end{array}$ & $\begin{array}{l}3.85 \times 10^{6} \\
4.79 \times 10^{6}\end{array}$ & $\begin{array}{l}14.93 \times 10^{6} \\
14.93 \times 10^{6}\end{array}$ & $\begin{array}{l}19.30 \times 10^{6} \\
19.72 \times 10^{6}\end{array}$ & $\begin{array}{l}4.54 \times 10^{5} \\
4.82 \times 10^{5}\end{array}$ & $\begin{array}{l}4.48 \times 10^{5} \\
4.48 \times 10^{5}\end{array}$ & $\begin{array}{l}9.02 \times 10^{5} \\
9.30 \times 10^{5}\end{array}$ & $\begin{array}{l}1.45 \times 10^{6} \\
1.47 \times 10^{6}\end{array}$ \\
\hline
\end{tabular}


Table 4.4. Economics of ICES Compared to the Conventional System (1979 \$)

\begin{tabular}{|c|c|c|c|c|c|}
\hline Central Plant Type & $\begin{array}{l}\text { Incremental } \\
\quad \text { Capital } \\
\text { Investment }\end{array}$ & $\begin{array}{l}\mathrm{O} / \mathrm{M} \\
\text { Saving }\end{array}$ & $\begin{array}{l}\text { Straight Payback } \\
\text { (Years) }\end{array}$ & $\begin{array}{l}\text { Internal Rate } \\
\text { Return (\%) }\end{array}$ & of \\
\hline \multicolumn{6}{|l|}{ Internal Combustion Engines } \\
\hline $\begin{array}{l}\text { Diesel Engines } \\
\text { Gas Engines } \\
\text { Dual-Fuel Engines }\end{array}$ & $\begin{array}{l}9.24 \times 10^{6} \\
6.10 \times 10^{6} \\
8.81 \times 10^{6}\end{array}$ & $\begin{array}{l}2.87 \times 10^{5} \\
1.18 \times 10^{5} \\
1.45 \times 10^{5}\end{array}$ & $\begin{array}{l}20.0 \\
27.4 \\
29.5\end{array}$ & $\begin{array}{l}0 \\
0 \\
0\end{array}$ & \\
\hline \multicolumn{6}{|l|}{ Gas Turbines } \\
\hline $\begin{array}{l}\text { Gas Fired } \\
\text { Oil Fired }\end{array}$ & $\begin{array}{l}7.88 \times 10^{6} \\
8.37 \times 10^{6}\end{array}$ & $\begin{array}{l}2.88 \times 10^{5} \\
0.18 \times 10^{5}\end{array}$ & 17.5 & $\begin{array}{c}6.5 \\
0\end{array}$ & \\
\hline Heat-Pump-Centered System & $0.98 \times 10^{6}$ & $4.58 \times 10^{5}$ & 2.1 & 52 & \\
\hline \multicolumn{6}{|l|}{$\begin{array}{l}\text { Heat-Pump-Centered System } \\
\text { with River Water }\end{array}$} \\
\hline $\begin{array}{l}\text { W/O River Water Return } \\
\text { With River Water Rəturn }\end{array}$ & $\begin{array}{l}1.91 \times 10^{6} \\
2.85 \times 10^{6}\end{array}$ & $\begin{array}{l}5.39 \times 10^{5} \\
4.91 \times 10^{5}\end{array}$ & $\begin{array}{l}3.3 \\
5.2\end{array}$ & $\begin{array}{l}33 \\
21\end{array}$ & \\
\hline
\end{tabular}


be offset by savings in the operation of the system and thereby justify the implementation of an ICES. Column 2 of Table 4.4 shows savings in operation ( $t$ ax benefits, such as depreciation and investment $t$ ax credits, are not included). Straight payback periods, listed in the third column, represent the number of years that the incremental capital expenditure can be compensated due to the simple accumulation of savings in operation. The internal rate of return on the incremental capital expenditure, provided in column 4, gives the discount rate at which the accumulated operation cost savings over the life of the ICES plan just balance the incremental investment. Savings in operating costs are assumed to increase at a conservative annual rate of $5 \%$. The life of the ICES plant is assumed to be 20 yrs.

\subsection{CONCLUSION}

Based on the evaluation criteria, the heat-pump-centered ICES without using river water will have:

- fastest payback,

- highest internal rate of return,

- lowest incremental capital expenditure,

- fair scarce fuel savings,

- fair energy savings, and

- high reliability.

of all the systems studied, the heat-pump-centered ICES stands out as the best way to proceed in today's economy. 


\section{THIS PAGE}

\section{WAS INTENTIONALLY \\ LEFT BLANK}




\section{DESCRIPTION OF THE RECOMMENDED SYSTEM HEAT-PUMP-CENTERED ICES}

\subsection{INTRODUCTION}

A heat pump operates as a refrigeration machine, i.e., it transfers heat from where the temperature is lower (evaporator) to where the temperature is higher (condenser). It can provide simultaneous heating and cooling. If water is circulated through the evaporator, it will be chilled and can be pumped to the buildings for cooling. If water is circulated through the condenser, heat will be absorbed and may be used for heating. When simultaneous heating and cooling requirements just balance each other, the heat pump simply transfers heat from one part of the building to another. However, if cooling demand is much larger than the heating demand, the higher temperature side would become increasingly hotter, and a heat sink should be provided to dissipate the undesirable heat. On the other hand, when heating demand exceeds the heat extracted from the cooling loop plus the compression heat, a heat source is required.

The interior areas of the office buildings and shopping mall of the Gallery II Complex, which consist of no walls adjacent to the ambient air, require cooling during the heating season because of the internal heat generation due to lighting, operation of machines, and people in these interior zones. It is conventionally removed by using an economizer cycle which mixes cold outside air with hot return air. With the application of heat pumps, the economizer cycle can be eliminated and the cooling of the interior zones can be provided by operating heat pumps. The heat removed from the cooling loop by the heat pumps' evaporator is reclaimed by the condenser and pumped through the heating loop to heat periphery zones. However, the heat recovered is normally not sufficient to satisfy the total heating load. Therefore, auxiliary boilers, sized to supplement the heating demand, are installed in parallel with the heating loop. The heat pumps used for this system have two tube bundles. One is used for heating, and the other for the cooling tower.

\subsection{HF.AT-PIMP SYSTEM OPERATION}

Figure 5.1 shows the central plant of the heat-pump-centered ICES. For simplicity, a one-stage heat pump is shown instead of the double-stage unit actually used.

The heat pump operates to satisfy the cooling load of the community. Its stop-start and capacity modulation is controlled solely by the temperature controller TC 1 which senses the temperature of leaving chilled water, and controls the operation of heat pump accordingly through the pneumatic electric switch PE 1 .

In a cooling season when no heating is required, all the heat carried by the chilled water loop is pumped from the evaporator to the condenser which, in turn, dissipates it to the cooling towers. The thermostat, TC 2, controls the condenser water temperature and, when called, activates the cooling tower fan whch is interlocked with cooling tower water pumps. 


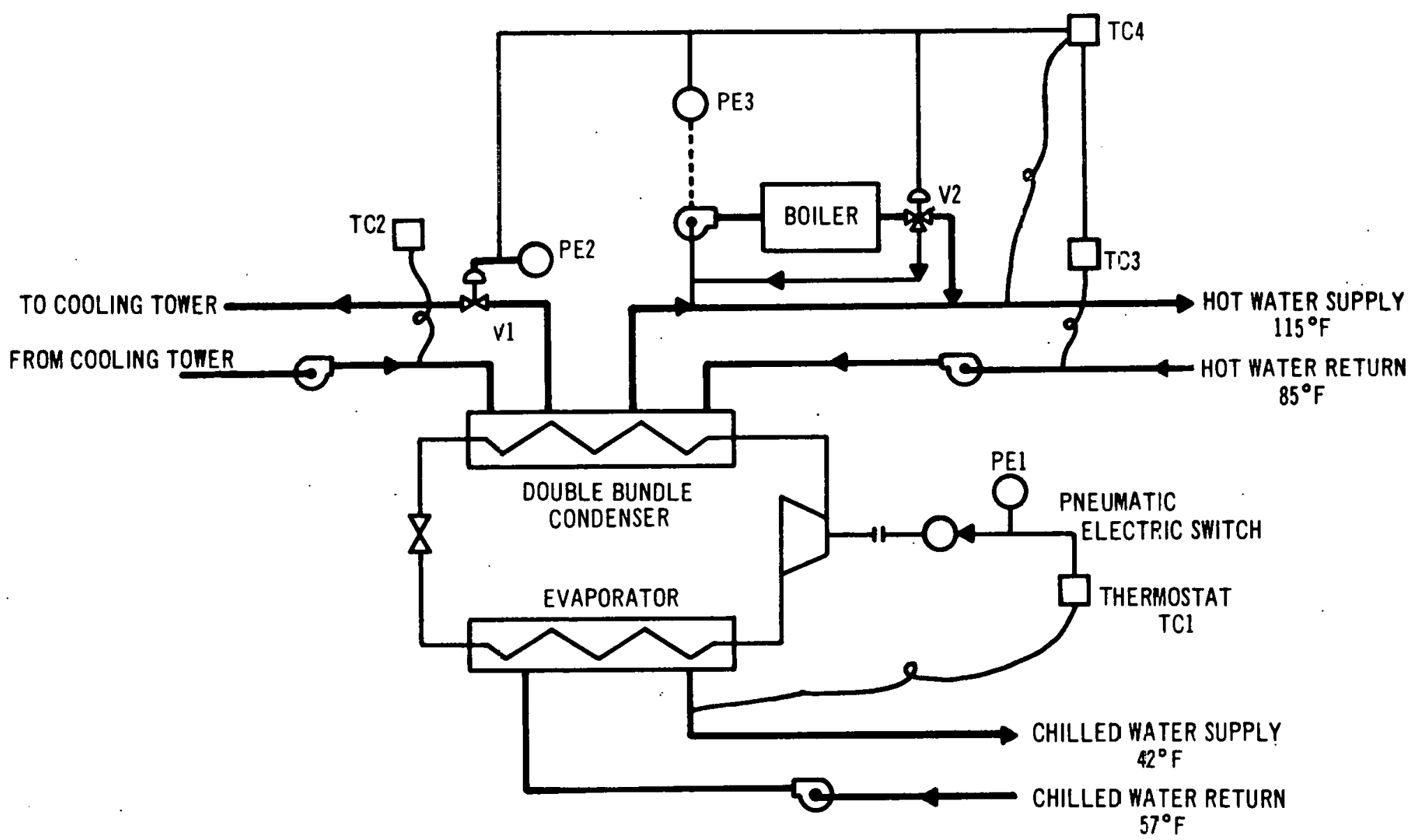

Fig. 5.1. Schematic of Heat-Pump Centered ICES 
When demand for heat increases, the temperature controller, TC 3 , senses the drop in return hot water temperature and transmits the signal to TC 4, which slowly closes valve $\mathrm{Vl}$, and reduces the amount of heat rejected to the cooling tower. This increases the heat rejected to the heating bundle and raises the exiting hot water temperature. If this fails to increase the temperature to the required value, TC 4 closes Vl completely and starts to open valve V2 and activates PE 3 to start the boiler pumps. This feeds heated boiler water into the loop.

A reverse sequence of events occurs when the heating load decreases. 
THIS PAGE

\section{WAS INTENTIONALLY \\ LEFT BLANK}




\section{RECOMMENDATION}

Based on the preceeding analysis, the heat-pump-centered ICES with heat redistribution uses commercially available technology and, of the systems studied, was shown to be the most attractive system for meeting the energy requirements of the Gallery II Complex.

The heat-pump-centered ICES concept is recommended for Gallery II, and consulting engineers. should be hired to perform preliminary and final system design. 


\section{THIS PAGE}

\section{WAS INTENTIONALLY \\ LEFT BLANK}


APPENDIX

INTRODUCTION TO INTEGRATED COMMUNITY ENERGY SYSTEM (ICES)

Traditionally, utility services such as heating, cooling, and lighting, have been served by separate energy forms and supply systems. Because most existing building and energy supply systems were designed when energy was cheap and abundant, few attempts were made to conserve energy. However, increasingly higher prices of energy and uncertain supplies of oil and natural gas have created a need to: (1) increase efficiency in the ways fuels are used, and (2) replace scarce fuels with more abundant fuels.

One factor responsible for the inefficiency of conventional energy supply systems is the lack of coordination among the various systems supplying different energy services. For example, a conventional electrical generating plant utilizes only about one-third of its fuel input energy, and rejects great amounts of heat to the environment. At the same time, scarce fuels, such as oil and natural gas, are burned to provide heat for purposes such as space heating. One way to address this lack of coordination is through the concept of cogeneration. Cogeneration plants integrate conventionally separate energy supply processes by simultaneously generating electricity while recovering "waste" heat. This recovered heat then can be used for: (1) space and water heating, (2) space cooling with the aid of absorption chillers, and (3) other processes. By providing the useful application of otherwise wasted heat, cogeneration systems offer the potential to increase efficiencies of energy utilization and thus to conserve natural energy resources.

Furthermore, in a conventional, decentralized system, each user would install its own energy conversion devices, such as chillers and boilers, to serve the energy needs of the building. Little coordination exists among users in a community. It may happen that one building uses energy to reject heat, while the other building consumes energy to keep warm. Integration of energy users not only would make efficient use of valuable energy, but also would take advantage of diversity of energy demands of different users and thereby decrease the capacity of energy conversion equipment.

An ICES generally has three main components: (1) the central plant, (2) distribution systems, and (3) end-use devices. The central plant converts primary fuels, such as coal, solid waste, geothermal, solar energy, oil, gas, biomass, or wind, into more readily usable forms of energy, such as electricity, steam, and hot or chilled water. A typical cogeneration plant consists of the following components:

(1) fuel storage and supply steam,

(2) prime movers with electric generators, such as internal combustion engines, steam turbines, gas turbines, fuel cells, etc.,

(3) heat recovery systems, such as heat recovery boilers or heat exchangers,

(4) unserviceable lieat rejection system,

(5) cooling devices, such as absorption chillers, and compression chillers, 
(6) auxiliary heating devices,

(7) water treatment devices, and

(8) control and metering devices.

The distribution system transports the energy produced in the central plant to consumers. End-use devices link the energy distribution system to the site where energy will be used.

An ICES can provide all the community's basic utility needs (those for space heating, space cooling, domestic hot water, electricity, process steam, etc.) or part of them. It could operate independently of existing electric utilities, or it may be "grid-connected," and capable of buying or selling electricity from or to the utility grid.

Sites with high potential for ICES implementation include places with high utility rates, high demand density, and new developments. Typical applications include:

$$
\begin{aligned}
& \text { university campuses, } \\
& \text { medical complexes, } \\
& \text { office complexes, } \\
& \text { industrial parks, }
\end{aligned}
$$

urban renewal projects, downtown areas, military bases, and commercial complexes. 


\section{ACKNOWLEDGMENTS}

The authors wish to acknowledge the individuals and organizations who helped in the preparation of this document.

Grateful appreciation to:

- Ms. Elizabeth Donnelly, Mr. Lucien Calhoun, and other CCEMP staff of the City of Philadelphia who spent many hours answering numerous requests for information.

- Mr. Gerald M. Maler and Mr. Avrum Kantor, Market Street East Development Corporation, who helped by supplying maps and many vital pieces of local information.

- Mr. Howard Davis, ESCOR Inc., for helpful discussions.

- Mr. Donald Clifford, ANL CCEMP Project Director, who assisted in laying the initial organization arrangements between the City and ANL.

Special thanks to Ms. Carol Gutowski, Ms. Yanick Atkins, Ms. Jo Ann Lawlor, Ms. Kathy Fischer and Ms. Susan Janowski who typed this report; Ms. Barbara Biederman who edited the report; Ms. Linda Samek and Ms. Mary Jo Koelbl who drafted the illustrations.

The original drawings on pages $1,4,5$, and 6 were taken from The Gallery at Market Street East, Cope Linder Walmsley, Architects, Philadelphia, Pennsylvania (1978). 